\title{
Flora da Reserva Ducke, Amazonas, Brasil: Pteridophyta \\ Chave Para as famílias
}

Jefferson Prado ${ }^{1}$

1. Lâmina com uma única nervura.

2. Plantas homosporadas; lâmina desprovida de lígula Lycopodiaceae

2. Plantas heterosporadas; lâmina com lígula Selaginellaceae

1. Lâmina com venação ramificada, aberta ou areolada.

3. Esporângios reunidos em sinângio, desprovidos de ânulo.

4. Sinângios na base da lâmina, em forma de espiga, ereta

4. Sinângios na face abaxial da lâmina, elípticos, sésseis

Ophioglossaceae

3. Esporângios separados entre si, com ânulo ocupando diferentes posições

5. Esporângios sésseis ou subsésseis; ânulo lateral, apical ou oblíquo, não interrompido pelo pedicelo.

6. Esporângios piriformes; ânulo apical

Schizaeaceae

6. Esporângios globosos; ânulo oblíquo.

7. Soros marginais; esporos com clorofila

7. Soros abaxiais; esporos sem clorofila.

8. Plantas herbáceas; frondes pseudodicotomicamente divididas ..... Gleicheniaceae

8. Plantas arborescentes ou herbáceas; frondes pinadas.

9. Plantas arborescentes; pecíolo com escamas e tricomas ou somente com escamas

Cyatheaceae

9. Plantas geralmente herbáceas, às vezes arbóreas; pecíolo sem escamas, somente com tricomas

Metaxyaceae

5. Esporângios pedicelados; ânulo longitudinal interrompido pelo pedicelo.

10. Pecíolo com 2 feixes vasculares na base.

11. Indumento formado de tricomas unicelulares, aciculares, bifurcados ou estrelados; soros arredondados a alongados (não lineares) ou acrosticóides ..... Thelypteridaceae

11. Indumento formado de tricomas pluricelulares; soros lineares Aspleniaceae

10. Pecíolo com 1, 3 ou mais feixes vasculares na base.

12. Soros alongados a lineares, paralelos e adjacentes à costa

Blechnaceae

12. Soros arredondados, alongados ou cônicos e oblíquos em relação à costa ou lineares, paralelos e próximos da margem da lâmina ou esporângios formando soros acrosticóides.

13. Caule reptante; pecíolo articulado com o caule e frondes dispostas em duas fileiras sobre o lado dorsal do caule; lâmina geralmente pinatissecta a 1-pinada, inteira ou subdicotomicamente furcada Polypodiaceae

13. Caule ereto ou reptante; pecíolo não articulado com o caule ou às vezes articulado e frondes, em ambas as situações, dispostas espiraladamente no caule; lâmina inteira até 5-pinada ou raramente furcada.

14. Lâmina inteira a pinatífida ou furcada, ou apenas 1-pinada com pinas não dimidiadas.

15. Esporos com clorofila

Grammitidaceae

15. Esporos sem clorofila.

${ }^{1}$ Instituto de Botânica, Seção de Briologia e Pteridologia. C.P. 4005, CEP 01061-970. São Paulo, SP, Brasil. 
16. Frondes dimorfas

Lomariopsidaceae

16. Frondes monomorfas.

17. Soros arredondados; indúsio reniforme

Davalliaceae

17. Soros lineares a alongados; indúsio ausente Vittariaceae

14. Lâmina 1-2-pinada com pinas dimidiadas ou 1-4-pinado-pinatífida.

18. Soros lineares, marginais a submarginais.

19. Indúsio de origem abaxial presente

Dennstaedtiaceae

19. Indúsio de origem abaxial ausente Pteridaceae

18. Soros arredondados ou acrosticóides.

20. Raque, costa e cóstula conspicuamente sulcadas adaxialmente, sulcos decorrentes entre si; indúsio peltado ou ausente

Dryopteridaceae

20. Raque, costa e cóstula não sulcadas adaxialmente ou levemente sulcadas, sulcos não decorrentes entre si; indúsio reniforme Tectariaceae

*A família Hymenophyllaceae não é tratada no presente estudo. 
